УДК 343.13

DOI https://doi.org/10.32849/2663-5313/2020.9.32

\title{
Валентина Дрозд,
}

докт. юрид. наук, доиент,

стариий науковий співробітник, начальник 3-го відділу

науково-дослідної лабораторії проблем правового

та організачійного забезпечення діяльності Міністерства

Державного науково-дослідного інституту

Міністерства внутрішніх справ Украӥни

\section{СУДОВА ПРАКТИКА \\ ЩОДО ДОПУСТИМОСТІ ДОКАЗІВ, ОТРИМАНИХ У РЕЗУЛЬТАТІ ПРОВЕДЕННЯ НЕГЛАСНИХ СЛІДЧИХ (РОЗШУКОВИХ) ДІЙ}

У статті визначено проблемні питання визнання допустимими доказів, отриманих у результаті проведення негласних слідчих (розшукових) дій на підставі судової практики: використання матеріалів, які не відкриті в порядку ст. 290 КПК України з підстав таємності; співвідношення огляду електронних засобів, вилучених під час обшуку з втручанням у приватне спілкування; використання відомостей негласних слідчих (розшукових) дій у разі зміни кваліфікацї злочину на менш тяжкий; недопустимість доказів, отриманих неналежни суб'єктом. Наголошено, що допустимість доказів, отриманих у результаті проведення негласних слідчх (розшукових) дій, визначається за загальними критеріями їх допустимості: 1) дотримання процесуальної форми отриманих доказів; 2) збирання доказів належним суб'єктом кримінального прочесу; 3) належне джерело отримання доказів; 4) належний спосіб отримання доказів. З'ясовано, що одним з аспектів допустимості доказів, отриманих у результаті негласних слідчих (розиукових) дій, є випадки, які стосуються приватного спілкування. Так, поширеною є практика огляду слідчим (прокурором) мобільних телефонів, планшетів, комп'ютерів, іншої електронної техніки, вилученої під час обшуку. Найпоширенішим способом процесуального оформлення діï, яка полягає в огляді та фіксачї електронної інформацї, що міститься на вилучених у межах інших процесуальних дій електронних пристроях, є також складання слідчим протоколу огляду в порядку ст. 237 КПК України. Визначено, що втручання у таємницю спілкування можливе лише на підставі судового рішення з метою виявлення та запобігання тяжкому чи особливо тяжкому злочину, встановлення його обставин, особи, яка вчинила злочин, якщо в інший спосіб неможливо досягти иієї мети. Тому вважаємо, що з метою недопущення порушення прав особи дочільно у клопотанні про проведення обшуку зазначати необхідність доступу до інформацій, яка може міститися в засобах електронної техніки, з обгрунтуванням такого доступу.

Ключові слова: негласні слідчі (розшукові) дії, відкриття матеріалів кримінального провадження іншій стороні, неналежний суб’єкт проведення негласної слідчої (розшукової) дії.

Актуальність теми. У теорії кримінального процесу наголошується, що введення до системи досудового розслідування інституту негласних слідчих (розшукових) дій (далі НС(Р)Д) є надзвичайно прогресивним кроком законодавця, який спрямований на їі удосконалення. Справді, надзвичайну актуальність має питання порядку проведення та використання в процесі доказування результатів НС(Р)Д. Але натепер є низка дискусійних питань щодо допустимості відомостей, отриманих під час проведення НС(Р)Д, як доказів та можливостей їх використання в кримінальному провадженні.

Стан дослідження. Питання допустимості доказів, отриманих у результаті про- ведення НС(Р)Д, у кримінальному провадженні викликають великий науковий інтерес та досліджувалися такими вченимипроцесуалістами, як Р. І. Благута, О. В. Геселев, О. В. Грибовський, О. В. Ковальова, А. В. Панова, О. М. Сало, С. Д. Скулиш, P. С. Тагієв, Б. В. Шабаровський, А. В. Шило, І. Л. Чупрікова тощо.

Метою статті є дослідження проблемних аспектів допустимості доказів, отриманих у результату проведення НС(Р)Д, з урахуванням судової практики.

Виклад основного матеріалу. 3 огляду на специфіку проведення НС(Р)Д та їх таємний характер, відмінні підстави 
та форми їх проведення, існує ряд особливостей збирання та перевірки доказів та використання ї результатів. Погоджуємося 3 науковою думкою про те, що закритий, конфіденційний характер НС(Р)Д об'єктивно зумовлює і проблему підтвердження достовірності отриманих у їх результату відомостей, їх оцінки з погляду належності та допустимості та, як наслідок, обгрунтування легітимності використання як доказів у кримінальному провадженні. Без можливості встановлення та перевірки під час досудового розслідування та судового розгляду кримінальної справи джерел інформації, що стали фактичною підставою для проведення НС(Р)Д, говорити про належність та допустимість отриманих фактичних даних, а також можливість повноцінного використання їх результатів для доказування не варто [1, с. 32].

Вважаємо, що допустимість доказів, отриманих у результаті проведення НС(Р) Д, визначається за загальними критеріями їх допустимості: 1) дотримання процесуальної форми отриманих доказів; 2) збирання доказів належним суб'єктом кримінального процесу; 3) належне джерело отримання доказів; 4) належний спосіб отримання доказів.

3 огляду на це, розглянемо проблемні аспекти визнання доказів, отриманих у результаті НС(Р)Д, недопустимими з урахуванням судової практики.

Одна 3 найбільш поширених підстав визнання доказів недопустимими - не відкриття частини матеріалів, отриманих у результаті НС(Р)Д, стороні захисту в порядку ст. 253, 290 КПК України. Відповідно до ч. 1 ст. 253 КПК України, особи, конституційні права яких були тимчасово обмежені під час проведення НС(Р)Д, а також підозрюваний, його захисник мають бути письмово повідомлені прокурором або за його дорученням слідчим про таке обмеження. При цьому, згідно з ч. 2 ст. 253 КПК України, конкретний час повідомлення визначається 3 урахуванням наявності чи відсутності загроз для досягнення мети досудового розслідування, суспільної безпеки, життя або здоров'я осіб, які причетні до проведення НС(Р)Д. Відповідне повідомлення про факт і результати НС(Р)Д повинне бути здійснене протягом 12 місяців з дня припинення таких дій, але не пізніше звернення до суду з обвинувальним актом [2]. При цьому до матеріалів провадження мають бути долучені ухвали слідчого судді про дозвіл на проведення НС(Р)Д, які тимчасово обмежують права людини, після відповідної процедури їх розсекречення. Така ухвала, безумовно, має особливе значення для оцінки отрима- них результатів вказаних дій як допустимих доказів. Але, як слушно зазначає О. В. Геселев, у такому випадку виникає проблема щодо процедури розсекречення або зняття грифу таємності 3 відповідної ухвали слідчого судді, без чого неможливо використовувати її для оцінки належності та допустимості доказів у гласному й відкритому судовому провадженні, оскільки на законодавчому рівні зазначене питання не врегульовано (за винятком відомчих інструкцій). У цьому разі пропонується застосовувати за аналогією відповідні приписи Інструкції, які встановлюють процедуру розсекречення інших процесуальних документів, що стали правовою підставою для проведення НС(Р)Д [1, с. 40]

Наведемо декілька прикладів судової практики із зазначеного питання.

Так, згідно 3 постановою Верховного суду, у кримінальному провадженні на виконання вимог ст. 290 КПК України стороною обвинувачення не було надано обвинуваченому та його захисникам для ознайомлення ухвали слідчого судді апеляційного суду, на підставі яких у кримінальному провадженні проводилися НС(Р)Д. При цьому сторона обвинувачення зверталася до апеляційного суду з клопотанням про розсекречення та скасування грифу секретності матеріальних носіїв інформації щодо проведення НС(Р)Д, у задоволенні якого апеляційним судом було відмовлено на підставі неналежного оформлення та відсутності всіх необхідних документів для розгляду клопотання щодо розсекречення матеріальних носіїв інформації. Протягом судового розгляду кримінального провадження в судах першої та апеляційної інстанцій стороною обвинувачення не вживалося заходів щодо розсекречення ухвал слідчого судді апеляційного суду про надання дозволів на проведення НС(Р)Д та відкриття їх стороні захисту, незважаючи на такі клопотання. 3 викладеного вбачається, що сторона обвинувачення не вжила всіх необхідних і достатніх заходів для повторного звернення до апеляційного суду з клопотанням про розсекречення матеріалів, які стали процесуальною підставою для проведення НС(Р)Д. Таким чином, протоколи зазначених НС(Р)Д визнані судом недопустимими доказами [3].

Разом із тим у кожному конкретному випадку під час вирішення питання про допустимість таких доказів суду необхідно враховувати всі обставини та неможливість відкриття матеріалів НС(Р)Д з незалежних від сторони обвинувачення причин. Зокрема, якщо сторона обвинувачення під час досудового розслідування своєчасно вжила всіх необхідних і залежних від неї заходів, спря- 
мованих на розсекречення процесуальних документів, які стали підставою для проведення НС(Р)Д, однак такі документи не були розсекречені з причин, що не залежали від волі та процесуальної поведінки прокурора, суд не може автоматично визнавати протоколи НС(Р)Д недопустимими доказами 3 мотивів не відкриття процесуальних документів, якими санкціоноване їх проведення.

3 цього питання важливою є постанова Великої палати Верховного суду у справі № 751/7557/15-к від 16.01.2019, до прийняття якої у випадках неможливості відкриття прокурором матеріалів НС(Р)Д протокол НС(Р)Д не використовувався як доказ, попри об'єктивні причини. Така відмова в розсекреченні на стадії досудового розслідування автоматично призводила до визнання доказів недопустимими без надання причинам нерозсекречення об'єктивної правової оцінки судом. I це мало місце попри те, що прокурор не має жодного процесуального засобу вплинути на ситуацію або змінити іiі.

Як зазначила суддя Верховного Суду Н. Антонюк, у таких випадках потрібно враховувати особливості процедури розсекречення зазначених матеріалів, результат якої залежить не лише від сторони обвинувачення. Адже прокурор не є самостійним суб'єктом розсекречення. Він зобов'язаний звернутися 3 відповідним клопотанням до експертної комісії з питань таємниць, яка й приймає відповідне рішення з урахуванням державних інтересів щодо збереження інформації в таємниці. Тільки після розсекречення прокурор може долучити їх до матеріалів провадження. Якщо ж комісія не розсекретить таких документів через загрозу заподіяння шкоди державним інтересам, то, відповідно, їх відкриття стороні захисту в порядку ст. 290 КПК України з урахуванням попередніх правових позицій Верховного Суду України та Великої Палати Верховного Суду стає неможливим. Отже, у правозастосовній практиці не виключена ситуація, за якої надання дозвільних документів на проведення НС(Р)Д на цій стадії може виявитися просто неможливим 3 огляду на державні та інші охоронювані законом інтереси, які полягають у збереженні певної інформації в таємниці [4].

Таким чином, Суд дійшов висновку, що процесуальні документи про надання дозволу на проведення НС(Р)Д не є самостійним доказом. Відповідно до ст. 84 КПК України, доказами є фактичні дані, отримані в передбаченому КПК України порядку, на підставі яких слідчий, прокурор, слідчий суддя й суд установлюють наявність чи відсутність фактів та обставин, що мають значення для кримінального провадження та підлягають доказуванню. А процесуальними джерелами доказів є показання, речові докази, документи, висновки експертів. Процесуальні ж документи, які стали підставою для проведення НС(Р)Д, не є документами в розумінні ч. 2 ст. 99 КПК України, оскільки не містять зафіксованих і зібраних оперативними підрозділами фактичних даних про протиправні діяння окремих осіб або групи осіб. Отже, процесуальні документи про дозвіл на проведення НС(Р)Д (у тому числі й відповідна ухвала слідчого судді) повинні досліджуватися під час розгляду справи в суді з метою оцінки допустимості доказів, здобутих у результаті НС(Р)Д. Тому Велика Палата Верховного Суду в постанові від 16.10.2019 вказала на те, що суди не можуть автоматично виключати такі протоколи НС(Р)Д лише з підстав, що відсутні дозвільні документи на іх проведення в матеріалах справи, не з'ясувавши спочатку причини їх відсутності. Натомість суди мають детально вивчати ситуації, чому такі дозвільні документи не були розкриті стороні захисту на етапі завершення розслідування [5].

Ще одним аспектом допустимості доказів, отриманих у результаті НС(Р)Д, є випадки, які стосуються приватного спілкування. Так, поширеною є практика огляду слідчим (прокурором) мобільних телефонів, планшетів, комп'ютерів, іншої електронної техніки, вилученої під час обшуку. Найпоширенішим способом процесуального оформлення дії, яка полягає в огляді та фіксації електронної інформації, що міститься на вилучених у межах інших процесуальних дій електронних пристроях, є також складання слідчим протоколу огляду в порядку ст. 237 КПК України. При цьому, зважаючи на необхідність спеціальних знань для проведення вказаної дії, такого роду огляд проводиться із залученням спеціаліста, завдання якого й полягає у тому, щоб виявити інформацію в електронному пристрої, що досить часто вимагає застосування спеціального програмного забезпечення (використовуються програми «UFED Physical Analyzer», «Мобільний криміналіст» та інші) [6, с. 76-89], [7]. Натомість стороною захисту досить часто ставиться питання про визнання результатів такого огляду недопустимими доказами, зважаючи на те, що мало місце втручання у приватне спілкування. При цьому судові рішення з даного питання є протилежними. Зокрема, одні судді не вбачають у процедурі такого огляду ознак втручання у приватне спілкування та визнають протоколи огляду допустимими доказами [8]. Інші суди в аналогічних випадках прислуховуються до 
позиції сторони захисту щодо того, що ознайомлення 3 інформацією 3 електронного пристрою є втручанням у приватне спілкування, та визнають протоколи огляду недопустимими доказами [9], [10, с. 106].

09 квітня 2020 року Друга судова палата Касаційного кримінального суду Верховного Суду у справі № 727/6578/17 прийняла рішення, в якому зазначила, що у разі огляду мобільного телефону, вилученого в ході обшуку, немає жодних порушень вимог кримінального процесуального закону.

Зокрема, у кримінальному провадженні, яке розглядалося судом, інформація, яка була наявна в мобільному телефоні підозрюваного, була досліджена шляхом включення телефону та огляду текстових повідомлень, які в ньому знаходились та доступ до яких не був пов'язаний із наданням володільцем відповідного серверу (оператором мобільного зв’язку) доступу до електронних інформаційних систем. У даному випадку орган досудового розслідування провів огляд предмета - телефона - та оформив його відповідним протоколом, який складений 3 дотриманням вимог кримінального процесуального закону [11].

3 цього приводу зазначимо, що у разі огляду електронної техніки слідчим втручання в приватне спілкування у значенні зняття інформації з транспортних телекомунікаційних мереж не буде, оскільки дана НС(Р)Д передбачає «перехоплення» інформації в «онлайн» режимі і не стосується статичних електронних даних, якими є sms, електронні листи, повідомлення у різного роду месенджерах тощо. Але буде порушення такої засади кримінального провадження, як таємниця спілкування (ст. 14 КПК України), відповідно до якої кожному гарантується таємниця листування, телефонних розмов, телеграфної та іншої кореспонденції, інших форм спілкування. Втручання у таємницю спілкування можливе лише на підставі судового рішення з метою виявлення та запобігання тяжкому чи особливо тяжкому злочину, встановлення його обставин, особи, яка вчинила злочин, якщо в інший спосіб неможливо досягти цієї мети. Тому вважаємо, що в даному випадку з метою недопущення порушення прав особи доцільно у клопотанні про проведення обшуку зазначати необхідність доступу до інформації, яка може міститися в засобах електронної техніки, з обгрунтуванням такого доступу. При цьому також слід звертати увагу на тяжкість кримінального правопорушення.

Одним із критеріїв визнання доказів допустимими, $€$ отримання їх належним суб'єктом. Проведення НС(Р)Д не є винят- ком. Слушною є думка В. А. Колесника, що правомочність слідчого визначається тим, що проводити НС(Р)Д має право лише слідчий, який здійснює досудове розслідування злочину. У матеріалах кримінального провадження повинен бути процесуальний документ, що підтверджує повноваження на час проведення такої негласної процесуальної дії конкретного слідчого на здійснення досудового розслідування злочину одноособово або в складі групи слідчих як уповноваженої процесуальної особи. Інший слідчий, навіть того самого органу досудового розслідування, не може бути суб'єктом проведення негласної слідчої (розшукової) дії в цьому кримінальному провадженні [12, с. 84], [13, с. 3] У свою чергу, єдиною правовою підставою для проведення НС(Р)Д оперативними працівниками, а також складення протоколів за результатами їх проведення є письмове доручення слідчого (ч. 6 ст. 246 КПК України, ч. 1 ст. 41 КПК України). Зазначена норма деталізована у вироку Краматорського міського суду Донецької області, в якому зазначено, що в кримінальному провадженні стороною обвинувачення на порушення процесуального порядку не надано жодного письмового доручення на адресу оперативних працівників СБУ з наданням їм права проводити відображені у протоколах слідчі дії чи проводити негласні слідчі (розшукові) дії, з чого випливає факт проведення таких слідчих дій процесуально не уповноваженими на те особами, без правових на те підстав. Відповідно, носії інформації, на яких зафіксований хід проведення НС(Р)Д, та протоколи дослідження інформації, отриманої при застосуванні технічних засобів, 3 вищенаведених підстав $€$ недопустимими доказами та не можуть бути використані для прийняття процесуального рішення і обгрунтування обвинувачення відповідно до вимог ч. 2 ст. 86 КПК України [14]

Проблемним питанням у визначенні допустимості доказів, отриманих у результаті проведення НС(Р)Д, є питання їх допустимості у разі зміни кваліфікації злочину на менш тяжкий. Зокрема, більшість НС(Р)Д проводиться виключно у кримінальних провадженнях щодо тяжких або особливо тяжких злочинів (ч. 2 ст. 246 КПК України). Кримінальним процесуальним законодавством наслідки перекваліфікації злочинів для оцінки допустимості матеріалів НС(Р)Д не визначено. Тривалий час у науковому світі з цього питання ведеться дискусія. Зокрема, І. Л. Чупрікова пропонує однозначно визнавати недопустимимими такі докази та наголошує на необхідності доповнення ч. 2 ст. 87 КПК України положенням про те, що результати НС(Р)Д, 
передбачених статтями 260, 261, 262, 263 , 264 (у частині дій, що проводяться на підставі ухвали слідчого судді), 267, 269 269-1, 270, 271, 272, 274 КПК України, у разі зміни правової кваліфікації кримінального правопорушення на невеликої чи середньої тяжкості повинні визнаватися такими, що отримані з істотним порушенням прав людини [15, с. 138-139]. Інші науковці, зокрема А. В. Панова [16, с. 137], О. В. Геселев [1, с. 34], наголошують на можливості використання таких доказів у разі обгрунтування прокурором у суді того, що на момент прийняття рішення та проведення $\mathrm{HC}(\mathrm{P})$ Д встановлені обставини, які вказували на існування ознак саме тяжкого або особливо тяжкого злочину, тобто довести наявність на той час передбачених законом підстав для здійснення таких дій [1, с. 35].

Судова практика з цього питання також суперечлива. Зокрема, 01 квітня 2020 року Третя судова палата Касаційного кримінального суду прийняла рішення у кримінальному провадженні, в якому кримінальне правопорушення було перекваліфіковане 3 ч. 3 ст. 368 на ч. 3 ст. 354 КК України. Відповідно до ст. 12 КК України, зазначений злочин невеликої тяжкості. Вироком суду I інстанції обвинуваченого визнано невинуватим у вчиненні злочину, передбаченого ч. 3 ст. 354 КК України, та виправдано на підставі п. 1 ч. 1 ст. 373 КПК України за недоведеністю вчинення кримінального правопорушення. Апеляційним судом вирок суду I інстанції залишено без змін. На зазначене рішення апеляційного суду прокурором подано касаційну скаргу із зазначенням того, що, виходячи 3 приписів ч. 2 ст. 246 КПК України, орган досудового розслідування мав право здійснювати НС(Р)Д щодо виправданого, оскільки вони проводяться виключно у кримінальному провадженні щодо тяжких або особливо тяжких злочинів, а на момент отримання дозволу та їх проведення до ЄРДР було внесено відомості про кримінальне правопорушення за попередньою правовою кваліфікацією за ч. 3 ст. 368 КК України, тобто щодо тяжкого злочину. 3 цих підстав прокурор вважає допустимими докази, отримані за результатами проведення НС(Р)Д.

У зазначеному кримінальному провадженні проводився аудіо-, відеоконтроль особи на підставі ухвали судді апеляційного суду, а також контроль за вчиненням злочину у формі спеціального слідчого експерименту. Таким чином, суд вважає, що на момент прийняття вказаних процесуальних рішень у органу досудового розслідування та у слідчого судді апеляційного суду не було даних, які б давали можливість ствер- джувати, що обвинувачений не є службовою особою, оскільки наказ про призначення на посаду, посадова інструкція чи інший документ, що міг стверджувати цей факт, не перебував у розпорядженні слідства і будь-які дії, спрямовані на його отримання, могли б завадити документуванню протиправної діяльності. 3 огляду на вищенаведене, відомості до ЄРДР вносились за заявою про вимагання неправомірної вигоди за правовою кваліфікацією за ч. 3 ст. 368 КК України, а тому НС(Р)Д проводились у межах кримінального провадження щодо тяжкого злочину.

Верховний суд прийняв рішення про призначення нового судового розгляду в суді апеляційної інстанції [17]. Отже, в даному випадку суд визнав матеріали НС(Р)Д допустимими доказами. 3 огляду на це, на нашу думку, в кожному конкретному випадку під час оцінки допустимості доказів (якщо злочин було перекваліфіковано на менш тяжкий) суду необхідно детально вивчати всі матеріали кримінального провадження на предмет того, чи була об'єктивна можливість визначення правильної кваліфікації кримінального правопорушення перед початком проведення НС(Р)Д. Або також можливий випадок, коли в ході проведення НС(Р)Д отримано нові докази, які вказують на інший склад кримінального правопорушення. Тому не можна однозначно визнавати докази, отримані в результаті НС(Р)Д, недопустимими на підставі зміни кваліфікації злочину на менш тяжкий.

\section{Висновки}

Таким чином, усі визначені питання є дискусійними та потребують подальших наукових досліджень. Вважаємо, що їх врахування під час оцінки доказів у кримінальному провадженні на предмет допустимості сприятиме додержанню прав його учасників, підвищенню якості роботи правоохоронних органів та додержанню законності під час прийняття судових рішень 3 огляду на преюдиціальне значення рішень інших судів у питаннях допустимості доказів.

\section{Список використаних джерел:}

1. Геселев О.В. Проблеми легітимізації використання результатів негласних слідчих (розшукових) дій для доказування у кримінальному провадженні. Науковий часопис Начіональної академії прокуратури України. 2018. № 1(17). С. 30-43. URL: http://www.chasopysnapu.gp.gov.ua/ua/pdf/ 1-2018/geselev.pdf. (дата звернення: 10.07.2020).

2. Кримінальний процесуальний кодекс України від 13.04.2012 року № 4651-VI. URL: http://zakon2.rada.gov.ua/laws/show/4651-17 (дата звернення: 11.07.2020). 
3. Постанова Верховного суду від 05.02.2019 року (справа № 552/6480/17). URL: http://www.reyestr.court.gov.ua/Review/ 87517403 (дата звернення: 10.07.2020).

4. Антонюк Н. Висновки Верховного Суду щодо відкриття матеріалів НСРД у порядку ст. 290 КПК України. URL: https://precedent.ua/ 2110000716?fbclid=IwAR021zdd4rxXdnAA_oETJ UcVPbz7talxmGGxgWPSeUGeBrsljecqa_m_ZLA (дата звернення: 10.07.2020).

5. Постанова Верховного суду від 16.01.2019 року (справа № 751/7557/15-к) URL: http://reyestr.court.gov.ua/Review/79298340 (дата звернення: 12.07.2020).

6. Шепітько В.Ю., Журавель В.А. Інноваційні засади техніко-криміналістичного забезпечення діяльності органів кримінальної юстиції : монографія. Харків: Апостиль, 2017. 260 с.

7. Леонов А. Як довести, що протокол огляду мобільного телефону чи комп'ютера є недопустимим доказом. Закон і бізнес. 2020. № 14 (1468). URL: https://zib.com.ua/ua/142223-yak_dovesti_ scho_protokol_oglyadu_mobilnogo_e nedopustimim d.html (дата звернення: 10.07.2020).

8. Ухвала Жовтневого районного суду м. Запоріжжя від 16.01.2017 року (справа №331/8071/15-к). URL: http://www.reyestr.court.gov.ua/Review/ 64135237 (дата звернення: 12.07.2020).

9. Вирок Орджонікідзевського районного суду м. Маріуполя Донецької області від 10.08.2016 року (справа №265/7387/15-к). URL http://www.reyestr.court.gov.ua/Review/ 59646144 (дата звернення: 12.07.2020).

10. Шило А.В. Використання в кримінальному провадженні відомостей, отриманих у результаті проведення негласних слідчих (розшукових) дій : дис. ... канд . юрид. наук за спеціальністю: 12.00.09. Харків, 2019. 233 с

11.Постанова Верховного Суду від 09.04.2020 року (справа №727/6578/17). URL http://reyestr.court.gov.ua/Review/88749345 (дата звернення: 12.07.2020)

12. Колесник В.А. Деякі окремі вимоги до складання протоколу негласних слідчих (розшукових) дій та додатків до нього. Часопис Академіи адеокатури Украӥни. 2015. Т. 8. № 4. С. 81-85.

13. Шабаровський Б.В. Особливості перевірки доказів, отриманих в результаті проведення негласних слідчих (розшукових) дій. Часопис Начіонального університету «Острозька академія». Серія «Право». 2019. № 1(19). URL http://lj.oa.edu.ua/articles/2019/n1/18sbvsrd.pdf (дата звернення: 10.07.2020)

14. Вирок Краматорського міського суду Донецької області від 25.11.2019 року (справа № 234/9080/15-к). URL: http://revestr.court.gov.ua/ Review/85857592 (дата звернення: 11.07.2020).

15. Чупрікова I. Л. Допустимість доказів у світлі нового Кримінального процесуального кодексу : дис. ... канд. юрид. наук : 12.00.09. Одеса, $2016.191 \mathrm{c}$.

16. Панова А. В. Особливості оцінки допустимості фактичних даних, отриманих у результаті негласних слідчих (розшукових) дій, як доказів у кримінальному провадженні. Вісник кримінального судочинства. 2016. № 1. С. 132-139.

17. Постанова Верховного Суду від 01.04.2020 року (справа № 607/15414/17) URL: http://www.reyestr.court.gov.ua/Review/ 88602316 (дата звернення: 20.07.2020).

Valentyna Drozd. Judicial practice on the admissibility of evidence obtained during the covert investigative activities

The purpose of the article is to study the problematic aspects of the admissibility of evidence obtained as a result of covert investigative (search) actions, taking into account the case law. The article identifies the problematic issues of recognition as admissible evidence obtained as a result of covert investigative (search) actions based on judicial practice: the use of materials not open in accordance with Art. 290 Code of Criminal Procedure of Ukraine on the basis of secrecy; the ratio of inspection of electronic means seized during the search to interference with private communication; the use of information of unspoken investigative (search) actions in the event of a change in the qualification of a crime to a less serious one; inadmissibility of evidence obtained by an inappropriate entity. It is emphasized that the admissibility of evidence obtained as a result of covert investigative (search) actions is determined by the general criteria of their admissibility: 1) compliance with the procedural form of the evidence obtained; 2) collection of evidence by a proper subject of criminal proceedings; 3) the appropriate source of evidence; 4) the appropriate method of obtaining evidence. It was found that one of the aspects of the admissibility of evidence obtained as a result of covert investigative (search) actions are cases involving private communication. Yes, it is common practice for investigators (search) to inspect mobile phones, tablets, computers, and other electronic equipment of persons seized during a search. The most common way of procedural registration of the action, which is to review and record electronic information contained in the electronic devices seized within other procedural actions, is also the compilation of the investigator's inspection report in accordance with Art. 237 of the Criminal Procedure Code of Ukraine. It is determined that interference with the secrecy of communication is possible only on the basis of a court decision to detect and prevent a serious or particularly serious crime, establish its circumstances, the person who committed the crime, if otherwise it is impossible to achieve this goal. Therefore, we believe that in order to prevent the violation of individual rights, it is advisable in the request for a search to indicate the need for access to information that may be contained in electronic equipment with a justification for such access.

Key words: secret investigative (search) actions, discovery of criminal proceedings to the other party, improper subject to conduct covert investigative (search) action. 